\title{
Treatment of domestic wastewater using an anaerobic baffled reactor followed by a duckweed pond for agricultural purposes
}

\author{
Fayza A. Nasr - Hala S. Doma - Hossaam F. Nassar
}

Published online: 8 October 2008

(c) The Author(s) 2008. This article is published with open access at Springerlink.com

\begin{abstract}
The treatment and reuse of domestic wastewater using an anaerobic baffled reactor (ABR) followed by a duckweed pond (DWP) were the main theme of the present study. The ABR was fed continuously with domestic wastewater at four HRTs ranging from 8 to $24 \mathrm{~h}$ and corresponds to organic loading rates ranging from 0.67 to $2.1 \mathrm{~kg} \mathrm{COD} / \mathrm{m}^{3} /$ day. The ABR effluent was fed to a DWP operating at 10 and 15 days. The performance of the ABR at the four HRTs gave satisfactory results. Chemical oxygen demand (COD) removal was between 68 and $82 \%$. Fecal coliform removal was between 1 to 2 logs. The $12-$ and 18-h hydraulic retention times (HRTs) gave close results, as indication of the possible selection of the 12-h HRT as the optimum operation for the ABR based on economic advantage. The ABR compartmentalized structure gave results higher than those produced by the onestage digester and similar to those produced by the twophase anaerobic digestion process. Duckweed ponds as post-treatment operated at 10 days and 15 days gave the best results at 15-day HRT, where it was possible to remove $73.4 \%$ of nitrogen and $65 \%$ of phosphorus and produce protein-rich dry duckweed of $105 \mathrm{~kg} / \mathrm{ha} /$ day on average. The removal of fecal coliform (FC) in duckweed ponds was 3-4 logs. The final treated domestic sewage characteristics proved its compliance with the Egyptian standards for reuse in restricted irrigation.
\end{abstract}

Keywords Anaerobic baffled reactor .

Domestic wastewater - Duckweed pond · Reuse ·

Treatment

F. A. Nasr $(\bowtie) \cdot$ H. S. Doma · H. F. Nassar

Water Pollution Control Department, National Research Center,

El-Tahrir Street, Dokki, Egypt

e-mail: Fayzanasr@hotmail.com

\section{Introduction}

Among the modern high-rate anaerobic reactors developed, the ABR looks promising for domestic wastewater treatment. The ABR was first developed by Batchmann et al. (1983) and described as a series of up-flow anaerobic sludge bed blankets (UASBs). This design consisted of a series of vertical baffles to force wastewater to flow up and down through a series of compartments containing the mixed anaerobes as they passed from the inlet to the outlet (Wanasen 2003). The anaerobic baffled reactor (ABR) maintains a high void volume without the need for expensive filter media and has a simple design with no special gas collection or sludge separation systems. Based on the study of Boopathy (1998), the four- and fivechamber ABRs appear to be slightly more efficient in converting solids and biogas compared with the two- and three-chamber ABRs. The anaerobic baffled reactor is simple to build and simple to operate. Hydraulic and organic shock loads have little effect on the treatment efficiency (Sasse 1998). The reactor also has good solids retention, and requires low maintenance and operational attentions. The anaerobic baffled reactor (ABR) avoids the risk of clogging and sludge bed expansion of the other systems, such as the anaerobic filter and UASB (Manariotis and Grigoropoulos 2002).

Langenhoff et al. (2000) stated that the most significant advantage of the ABR is its ability to separate acidogenesis and methanogenesis longitudinally down the reactor. This permits allowing the different bacterial groups to develop under most favorable conditions, and the reactor behaves as a two-phase system without the associated high cost-control problems. Two-phase operation can increase acidogenic and methanogenic activity by a factor of up to four as acidogenic bacteria accumulate within the first 
stage. Furthermore, when treating wastewater at low temperatures, the compartmentalization might enhance the hydrolysis of less biodegradable substrates in front of the reactor because of its low $\mathrm{pH}$.

Considering the advantages of the ABR and the characteristics of municipal wastewater, a modified ABR may be an economical anaerobic system for municipal wastewater treatment for tropical and subtropical areas of developing countries. An investigation was carried out at laboratory scale to explore the feasibility of the use of such a modified ABR with five compartments for municipal wastewater treatment at ambient temperatures ( $\mathrm{Yu}$ and Anderson 1996). The bench-scale ABR has been found to be effective for the treatment of high- as well as lowstrength soluble wastewaters.

The anaerobic process is efficient for the removal of organic material and suspended solids from municipal wastewater. However, the anaerobic process has little effect on the concentrations of nitrogen and phosphorus, whereas pathogenic organisms are only partially removed (Collivignarelli et al. 1990). Consequently, the anaerobic treatment is only to be considered a very effective pretreatment.

Post-treatment may be required for removing residual COD and total suspended solids (TSS), and to reduce the concentrations of nutrients and pathogens. Natural systems have a minimum dependence on mechanical elements; hence, they involve very low costs and low maintenance, and are particularly suitable for developing countries where money and skilled manpower are lacking (Conley et al. 1991). A stabilization pond is a typical kind of natural system for wastewater treatment. Duckweed ponds are a modified type of stabilization pond, covered with a floating mat of plants. The use of aquatic plants is a constructive approach for ammonia $\left(\mathrm{NH}_{3}\right)$ removal from wastewater. Instead of releasing the nitrogen to the atmosphere, it is trapped by the aquatic plants to produce protein-rich biomass. The direct conversion of ammonia into plant protein in a duckweed pond is a relatively highly energy efficient process compared to other alternative methods (Smith and Moclyowati 2001). The nitrogen in anaerobic effluent is present mainly as ammonia $\left(\mathrm{NH}_{4}{ }^{+}\right)$. This is an advantage because duckweed has a preferential uptake of ammonium over other sources of nitrogen $(\mathrm{N})$ (Porath and Pollock 1982). Therefore, duckweed can accumulate considerable amounts of nutrients that can be removed by simple and low-cost harvesting technologies. The harvested duckweed may be used as a valuable fish or animal feed (Skillcorn et al. 1993; El-Shafai et al. 2004). Korner et al. (2000) stated that Lemna gibba can be used to treat wastewater containing high total ammonia concentrations as long as certain $\mathrm{pH}$ levels have not exceeded 8.7 and maximum $\mathrm{NH}_{3}$ concentration levels $(8 \mathrm{mg} \mathrm{N} / \mathrm{l})$, above which duckweed died. He added that at $\mathrm{pH}$ of 7.8 , a substantial production of $55 \mathrm{~kg} \mathrm{DW} / \mathrm{ha} /$ day was achieved.

The aim of this work is to develop an environmentally sound and health-safe wastewater treatment system that can be implemented in small communities in Egypt.

\section{Materials and methods}

A treatability study was conducted to investigate the treatment of domestic wastewater using an anaerobic baffled reactor (ABR) followed by a duckweed pond. To accomplish the objectives of this study, laboratory scale models simulating an $\mathrm{ABR}$ reactor and duckweed pond were designed and manufactured. The treatment system was operated outdoors at ambient temperature in the experimental area of the Water Pollution Control Department of the National Research Center. The system was fed continuously with domestic wastewater from the public sewage network.

\subsection{Anaerobic baffled reactor (ABR)}

The ABR was made of Perspex material. It consisted of a series of vertical baffles that divided it into five identical compartments. The reactor was inoculated with anaerobic flocculent sludge from a sewage treatment plant in Cairo. The sludge content was maintained at around $15 \mathrm{~g} \mathrm{VSS} / 1$ flocculent sludge. The total liquid volume of the reactor is 15 l. Its length is $62 \mathrm{~cm}$, width $15 \mathrm{~cm}$, and height $17 \mathrm{~cm}$. A schematic diagram of the ABR reactor is presented in Fig. 1. The reactor was fed continuously with municipal wastewater through a connection from the sewerage system. The ABR was operated at different hydraulic retention times (HRT), and hence different organic loading rates (OLR), in order to arrive at the optimum operating conditions of the ABR. Table 1 shows the dimensions and operating conditions of the ABR.

\subsection{Duckweed pond}

A Perspex pond with $1,920 \mathrm{~cm}^{2}$ surface area, $52 \mathrm{~cm}$ depth, and effective volume of 1001 was used. Lemna gibba was chosen as the duckweed species in this study. The ABR effluent was fed to the duckweed pond, operating at two hydraulic retention times, 10 and 15 days. The duckweed pond was inoculated with Lemna gibba, obtained from a local drain at $600 \mathrm{~g}$ fresh duckweed per $\mathrm{m}^{2}$. The duck weed biomass was harvested once a week. The thickness of the residual lemna after harvesting was maintained at $600 \mathrm{~g} / \mathrm{m}^{2}$ (one layer). The harvested biomass was drained, weighed, and dried in an oven at $70^{\circ} \mathrm{C}$, and the dry matter content was calculated. 
Fig. 1 Schematic diagram of the anaerobic baffled reactor (ABR)

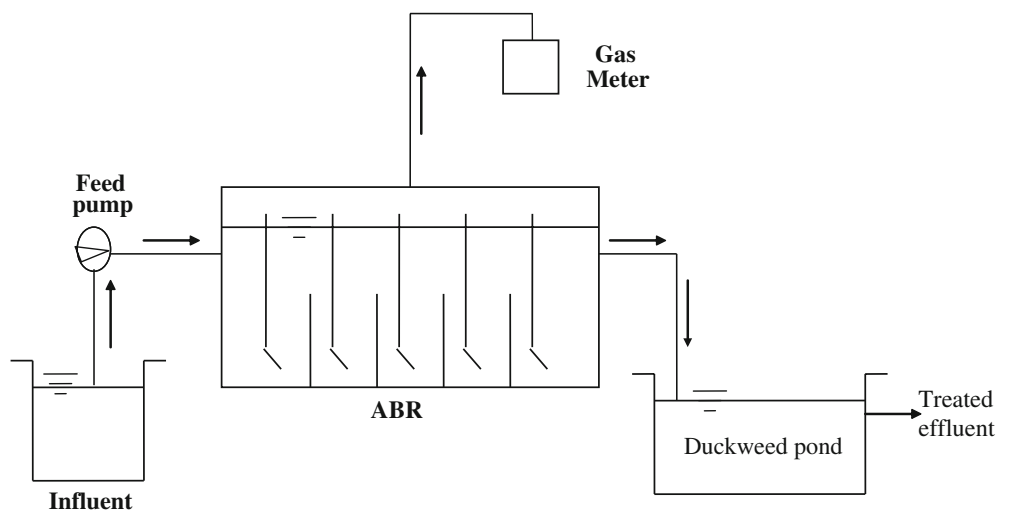

Table 1 Operating conditions of the anaerobic baffled reactor

\begin{tabular}{lllll}
\hline HRT $(\mathrm{h})$ & 24 & 18 & 12 & 8 \\
HLR $\left(\mathrm{m}^{3} / \mathrm{m}^{3} /\right.$ day) & 1 & 1.45 & 2 & 3 \\
OLR $\left(\mathrm{kg} \mathrm{COD} / \mathrm{m}^{3} /\right.$ day) & $(0.549-0.914)$ & $(0.856-1.05)$ & $(1.01-1.5)$ & $(1.87-2.2)$ \\
& $(0.669)^{\mathrm{a}}$ & $(0.958)^{\mathrm{a}}$ & $(1.3)^{\mathrm{a}}$ & $(0.2 .1)^{\mathrm{a}}$ \\
OLR $\left(\mathrm{kg} \mathrm{BOD} / \mathrm{m}^{3} /\right.$ day) & $(0.193-0.366)$ & $(0.400-0.521)$ & $(0.480-0.666)$ & $(0.862-1.2)$ \\
& $(0.262)^{\mathrm{a}}$ & $(0.452)^{\mathrm{a}}$ & $(0.585)^{\mathrm{a}}$ & $(0.925)^{\mathrm{a}}$ \\
Duration period (day) & 100 & 100 & 100 & 100 \\
\hline
\end{tabular}

${ }^{\text {a }}$ Average loading rate

\subsection{Sampling and analytical methods}

The performance of the treatment schemes was evaluated by monitoring the quality of the raw wastewater and effluent of each treatment unit. The physico-chemical characteristics, unless specified, were carried out according to the standard method (APHA 2002).

\subsubsection{Microbiological study}

The raw wastewater and treated effluents from each unit were subjected to microbiological investigation using fecal coliform as fecal pollution indicator. The fecal coliforms were counted by poured plate technique using membrane fecal coliform (mfc) (APHA 2002).

\subsubsection{Duckweed analysis}

The plant growth rate and yield were monitored once per week in the pond. The thickness of the residual cover after harvesting was maintained at $600 \mathrm{~g} / \mathrm{m}^{2}$ (one layer). The harvested biomass was drained, weighed, and dried in an oven at $70^{\circ} \mathrm{C}$. The dry matter content was calculated. The dry matter was powdered in a tissue grinder, and $0.2 \mathrm{~g}$ was used for organic $\mathrm{N}$ analysis. The protein content was calculated based on: protein $(\mathrm{g} / \mathrm{g})=$ organic $\mathrm{N}(\mathrm{g} / \mathrm{g}) \times 6.25$ (Rusoff et al. 1980). Then $0.1 \mathrm{~g}$ from the powder was taken and burned at $550^{\circ} \mathrm{C}$ for $1 \mathrm{~h}$. The ash was analyzed for phosphorus content using the per-sulphate digestion method (APHA 2002).

\subsubsection{Methanogenic activity assays}

The methanogenic activity is defined as the methane production rate of the sludge under potential conditions ( $\mathrm{g}$ $\mathrm{CH}_{4}-\mathrm{COD} / \mathrm{g}$ VSS/day). The specific methanogenic activity is commonly performed as a batch experiment in which a fixed amount of substrate is fed to a predetermined amount of sludge-solids as described by Field et al. (1988).

2.3.3.1 Total solids determination The mechanisms of total solids (TS) removal in the treatment units were evaluated by studying the mass of amount of TS in the effluent, amount of sludge formed inside the treatment tank, and amount of TS in the influent. A mass balance of TS removal is given in the following equation:

$\mathrm{TS}_{\text {inf. }}=\mathrm{TS}_{\text {eff. }}+\mathrm{TS}_{\text {accumulated }}+\mathrm{TS}_{\text {in tank }}+\mathrm{TS}_{\text {unaccounted }}$

where $\mathrm{TS}_{\text {inf. }}=\mathrm{TS}$ in the influent, $\mathrm{TS}_{\text {eff. }}=\mathrm{TS}$ in the effluent, $\mathrm{TS}_{\text {accumulated }}=\mathrm{TS}$ accounted sludge settling in the tanks, $\mathrm{TS}_{\mathrm{in} \mathrm{tank}}=\mathrm{TS}$ in the liquid part inside the tank, and $\mathrm{TS}_{\text {unaccounted }}=\mathrm{TS}$ that is unaccounted.

$\mathrm{TS}_{\text {accumulated }}$ was calculated from measuring the height of sludge accumulated in each compartment inside the tank, and the total volume of sludge accumulated in the tank was identified. The amount of sludge inside the tank 
was calculated by multiplying total sludge volume with the sludge's density. The total solid accumulated in the tank was finally calculated by multiplying the percentage of total solids with the amount of sludge calculated earlier. The $\mathrm{TS}_{\text {in tank }}$ was calculated by measuring the TS concentration from the samples taken from sampling ports at different compartments. After TS concentrations inside the tank were identified, the amount of TS in the liquid part was calculated by multiplying TS concentration with the liquid volume of that compartment.

\section{Results and discussion}

\subsection{Characteristics of raw wastewater}

Monitoring of the domestic sewage during this study indicated that the characteristics of domestic wastewater in terms of COD, biological oxygen demand (BOD), TSS, total Kjeldahl nitrogen (TKN), and total phosphorus (TP) were $682,289,279,61$, and $11 \mathrm{mg} / \mathrm{l}$, respectively (Table 2). The ratio of COD:BOD was around 2.3:1. These values are in agreement with Metcalf and Eddy (2005), who stated that for domestic sewage that can be treated successfully worldwide using a variety of biological treatment methods, the COD/BOD ratio varies from 1.5 to 2.

Volatile fatty acid concentration (VFA) in raw wastewater was around $38.9 \mathrm{mg} / \mathrm{l}$, which is comparable with the results obtained by Van der Last and Lettinga (1992). They suggested that the high concentration of VFA in the sewage was attributed to acidogenesis, which frequently takes place in the sewers.

Fecal coliform concentrations recorded an average value of $2.7 \times 10^{9}$. These values are in agreement with results obtained by Shereif et al. (1995), but are higher than the results reported by El-Hamouri et al. (1995). The higher value may be attributed to the lower rate of water discharge.

\subsubsection{Performance of the anaerobic baffled reactor}

Performance of the anaerobic baffled reactor (ABR) in this study was investigated using four organic loading rates, ranging between 0.67 and $2.1 \mathrm{~kg} \mathrm{COD} / \mathrm{m}^{3} /$ day. The results of monitoring the performance of the ABR at HRT of 8,12 , 18 , and $24 \mathrm{~h}$ (Table 3 ) indicated a higher efficiency of $82 \%$ COD removal at $24 \mathrm{~h}$ descending to $67.5 \%$ at $8 \mathrm{~h}$. Corresponding residual COD proportionally increases with the decrease of HRT. Similar results are observed with BOD, which scored $78 \%$ removal at $24 \mathrm{~h} \mathrm{HRT}$ and $62 \%$ at $8 \mathrm{~h}$. Total suspended solid percentage removals were $82,73.4$, 70.5 , and $68.9 \%$ at the HRT of $24,18,12$, and $8 \mathrm{~h}$, respectively. These results agree with those obtained by Wanasen (2003) operating the ABR at the same hydraulic retention time.

Anaerobic digestion is a mineralization process; consequently, little removal of nitrogen and phosphorus can be expected. The results of this study indicated that the removal of phosphorus at HRT of $24,18,12$, and $8 \mathrm{~h}$ were $36,31.2$, 30, and $29.7 \%$, respectively. These results are in line with results achieved by Wanasen (2003), who interpreted the phosphorus removal as being utilized for

Table 2 Characteristics of raw wastewater investigated in this study

\begin{tabular}{|c|c|c|c|c|}
\hline \multirow[t]{2}{*}{ Parameters } & \multirow[t]{2}{*}{ Unit } & \multicolumn{3}{|c|}{ Domestic wastewater } \\
\hline & & Min & Max & Average \\
\hline Temp. & $\mathrm{Mg} / \mathrm{l}$ & 22 & 28 & 24.4 \\
\hline $\mathrm{pH}$ & $\mathrm{Mg} / \mathrm{l}$ & 6.7 & 7.1 & 6.9 \\
\hline Tot. COD & $\mathrm{Mg} / \mathrm{l}$ & 505 & 914 & $682 \pm 154.1$ \\
\hline Sol. COD & $\mathrm{Mg} / 1$ & 210 & 369 & $293 \pm 79.5$ \\
\hline Tot. BOD & $\mathrm{Mg} / \mathrm{l}$ & 193 & 398 & $289 \pm 92.0$ \\
\hline Sol. BOD & $\mathrm{Mg} / \mathrm{l}$ & 95 & 200 & $128 \pm 53.7$ \\
\hline Ammonia & $\mathrm{Mg} / \mathrm{l}$ & 15 & 44 & $25 \pm 5.7$ \\
\hline TKN & $\mathrm{Mg} / \mathrm{l}$ & 39 & 79 & $61 \pm 12.0$ \\
\hline Tot. phosphorous & $\mathrm{Mg} / \mathrm{l}$ & 8 & 15 & $11 \pm 3.5$ \\
\hline TSS & $\mathrm{Mg} / \mathrm{l}$ & 158 & 488 & $279 \pm 98.0$ \\
\hline Oil and grease & $\mathrm{Mg} / \mathrm{l}$ & 34 & 106 & $67.7 \pm 36.0$ \\
\hline Sulphides & $\mathrm{Mg} / \mathrm{l}$ & 0.9 & 7 & $3.2 \pm 1.8$ \\
\hline VFA & $\mathrm{Mg} / \mathrm{l}$ & 30 & 44 & $38.9 \pm 7.1$ \\
\hline FC & $\mathrm{Cfu} / 100 \mathrm{ml}$ & $1.4 \mathrm{E}+07$ & $5.5 \mathrm{E}+10$ & $2.7 \mathrm{E}+09 \pm 2.1 \mathrm{E}+09$ \\
\hline
\end{tabular}

Average of 22 samples 


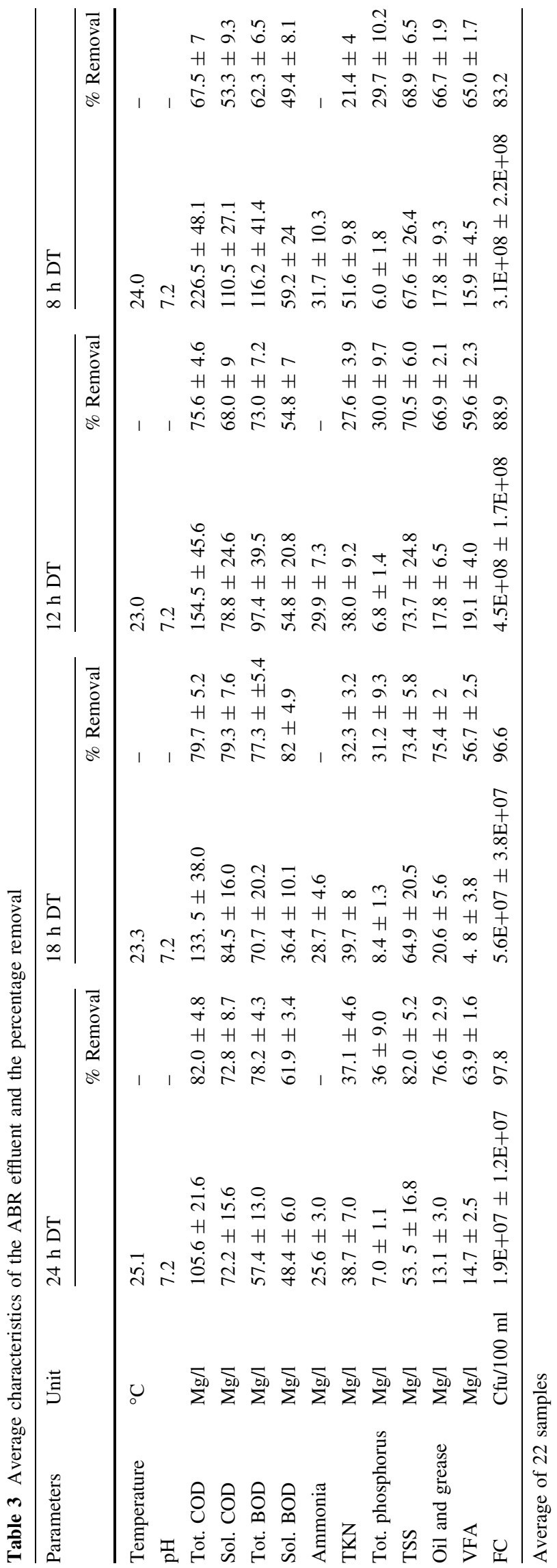

biomass growth and precipitated and entrapped with the digested sludge. The ammonia concentrations during HRT of $24,18,12$, and $8 \mathrm{~h}$ are increased by $49,27,21.6$, and $14 \%$, respectively. The removal values of total Kjeldahl nitrogen at the above-mentioned HRTs were 37.1, 32.3, 27.6 , and $21.4 \%$, respectively. These results correspond favorably to those obtained by Dama et al. (2005), who attributed the increase of ammonia concentration to degradation of biodegradable nitrogen compounds. He further explained the removal of non-biodegradable nitrogen compounds as they get entrapped in the sludge of the reactor.

Bacteriological examination of the ABR effluent revealed a removal of fecal coliform by 2 logs during HRT of 24 and $18 \mathrm{~h}$, while it was $1 \log$ at 12 and $8 \mathrm{~h}$ HRT. The drop in the fecal coliform concentration can be attributed to entrapments in the sludge in the reactor (Dama et al. 2005).

The results at $12 \mathrm{~h} \mathrm{HRT}$ are close to those at $18 \mathrm{~h}$ HRT: COD 80 and 76\%, BOD 77 and 73\%, and TSS 73.4 and $70.5 \%$, respectively. This slight difference indicates that the 12-h HRT is the optimum selection for operating the ABR for treating domestic wastewater at ambient temperature.

\subsection{The anaerobic baffled reactor compartment efficiency}

In the ABR, a series of vertical baffles forces the wastewater to flow up and down them as it passes from inlet to outlet. This configuration has been shown to result in a high degree of COD removal. The main advantage of using an ABR comes from its compartmentalized structure.

The results of this study indicated that the ABR overall COD removal efficiency at HRT of $24 \mathrm{~h}$ was $82 \%$. The total COD removal efficiency by compartments one through five was $62.9,29.4,13.9,12$, and $8 \%$, respectively. These results were also similar to those obtained by Kennedy and Barriault (2005), who reported that at HRT of $39 \mathrm{~h}$, the COD removal in compartment one was the highest, which reached $71 \%$ followed by $26 \%$ in compartment two and less than $2 \%$ in compartments three and four. Also Uyanik (2003) indicated that the highest COD removal occurred in the first compartment at HRT of $48 \mathrm{~h}$. From the available results, COD removal is shown to become gradually distributed across all five compartments as the HRT decreases from 24 to $8 \mathrm{~h}$, and as the HRT decreases, the last two compartments begin to play a major role in the COD removal (Fig. 2).

The decrease in the COD removal of the first and second compartments by lowering the HRT suggests that acidogenesis was predominating and that a more balanced methanogenic anaerobic consortium occurred mainly in the 
Fig. 2 Variation of relative COD removal in compartments

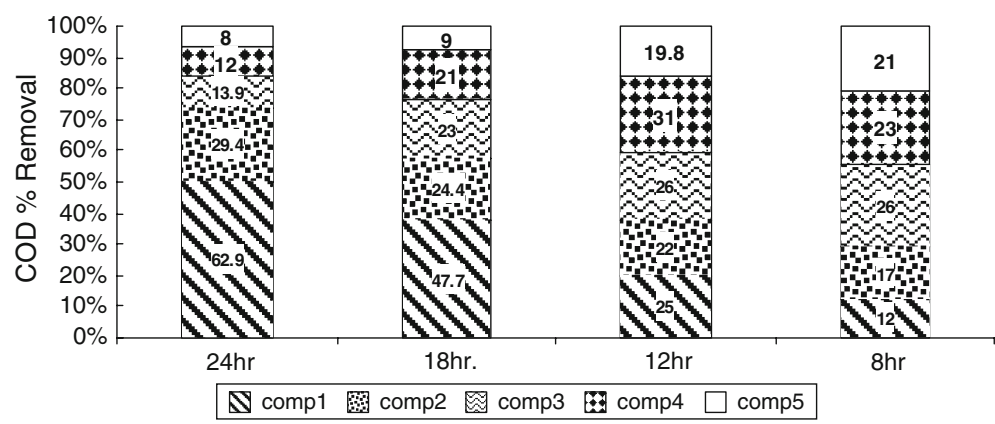

decreasing the HRT. The $\mathrm{pH}$ value in this compartment remains less than the corresponding values in all other compartments (Fig. 4).

These results are attributed to acidogenesis and acetogenesis phases that take place in the first and second compartments. Results achieved showed that the $\mathrm{pH}$ value in the third, fourth, and fifth compartments falls in the neutral zone. Methanogens are extremely sensitive to $\mathrm{pH}$ and work best under neutral conditions (latter compartments). Similar results were also established by Dama et al. (2005). The compartmentalized design of the ABR results in a buffering zone between the primary acidification zone and the active methanogenesis in the latter zones on the ABR (Nachiayasit and Stuckey 1997).

Increasing the OLR from 0.67 to $2.1 \mathrm{~kg} \mathrm{COD} / \mathrm{m}^{3} /$ day is associated with an increase in the methanogenic activity from 0.05 to $0.07 \mathrm{~g} \mathrm{CH}_{4}-\mathrm{COD} / \mathrm{g} \mathrm{VSS} /$ day in the first compartment and from 0.06 to 0.08 in the second compartment and so forth. At each organic load, the methanogenic activity progressively increased from the first compartment to the fifth compartment, and the highest increase was observed at the forth and fifth compartments. These results concur with the results obtained for the biogas production, which is highest in the fourth and fifth compartments. These results match those obtained by Langenhoff et al. (2000), who stated that the high methanogenic activity of the sludge was at the end of the reactor.

The results achieved showed that the biogas production rate is almost the same in the first three loads, but during the highest load, $2.1 \mathrm{~kg} \mathrm{COD} / \mathrm{m}^{3} /$ day, the biogas value

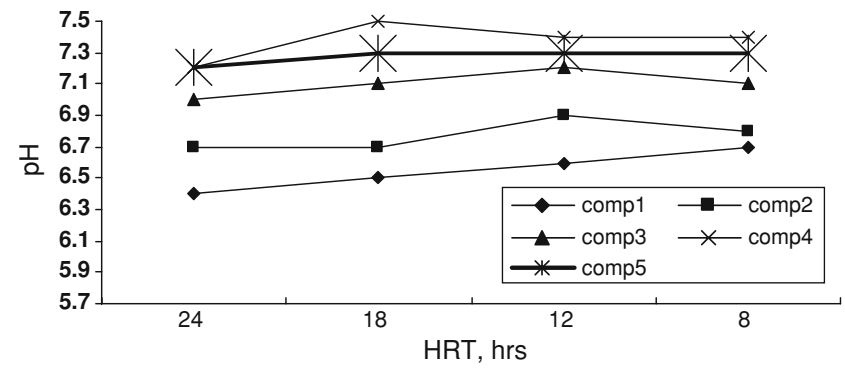

Fig. 4 The compartmental variation in the $\mathrm{pH}$

Fig. 3 Variation of the VFA concentration in compartments 
increased by $30 \%$ on average; it reached $0.455 \mathrm{~m}^{3}$ biogas/ $\mathrm{kg}$ COD removed on average. A similar conclusion was established by She et al. (2006), who found that the biogas production rate increased by increasing the organic load from 1.27 to $4.46 \mathrm{~kg} \mathrm{COD} / \mathrm{m}^{3} /$ day and began to decrease when the OLR was higher than $6.29 \mathrm{~kg} \mathrm{COD} / \mathrm{m}^{3} /$ day. From the results, it is shown that the ABR produced by biogas is higher than that produced by a one-stage UASB reactor and similar to that produced by two-stage UASB reactors operating at the same HRT and same organic loading rate (El-Gohary et al. 2000; Nasr et al. 1998). Boopathy (1998) concluded that the biogas production of the $\mathrm{ABR}$ was equal to or greater than other digester designs. This is attributed to the ability of the baffled reactor to effectively trap the small-diameter methanecontaining sludge particles and maintain a high solids retention time.

One of the ABR mechanisms is to remove solids by settling as sludge. The amount of solids accumulated in each compartment during this study at the different HRT indicated that the sludge accumulation is directly proportional to the increase of OLR and decrease of the HRT. Compartment-wise, the sludge accumulation was found to be highest in the first compartment and least in the fifth compartment. When operating the ABR at 24-h HRT, the results indicated values of $3.2,1.7$, and $1.5 \mathrm{~g} /$ day for accumulated TS, unaccumulated TS, and in-tank TS, respectively, whereas the effluent TS was $1.23 \mathrm{~g} /$ day (Table 4). When HRT decreased gradually until it reached $8 \mathrm{~h}$, the total solids increased until it reached $7 \mathrm{~g} /$ day, TS in tank, and the uncounted solids were $5.6 \mathrm{~g} /$ day. The results showed that the wash-out effect of solids increased by decreasing the HRT. The unaccounted TS could represent the solid degradation. At 24-h HRT, the unaccounted TS was very low, and it increased gradually during the rest HRT until it reached $5.6 \mathrm{~g} /$ day during 8-h HRT. This could explain why the biogas was very low during the first two HRTs and began to increase during the third and fourth HRTs.

\subsection{Performance of the duckweed pond (DWP)}

The results of the present study indicated that the ABR has great potential in removing total suspended solids and biological oxygen demand, but is deficient in removing pathogenic bacteria and nutrients. The nutrient-rich effluent from the ABR should be post-treated for removal of pathogenic bacteria and recovery of nutrients to produce an effluent suitable for irrigation. The ABR effluent 12-h HRT was fed alternatively to the duckweed pond working at 10- and 15-day HRTs, respectively. The duckweed pond was inoculated with Lemna gibba, obtained from a local drain at $600 \mathrm{~g}$ fresh duckweed per $\mathrm{m}^{2}$. The results showed that the COD removal ranged between 53.3 and $58.4 \%$, BOD removal ranged between 58.6 and $66 \%$, and TSS removal ranged between 52.4 and $44.1 \%$, respectively (Table 5). Oron and Willers 1989 observed COD and BOD removal values for Lemna gibba-covered mini-ponds of about 63 and 92\%, respectively, at 20-day total HRT using settled sewage.

The achieved results indicated that the photosynthetic activity of the duckweed raises the $\mathrm{pH}$ from 7.2 in the ABR effluent to 8.5 in the DWP effluent.

The removal of nitrogen and phosphorus ranged between 66.7 and $73.4 \%$ and between 53.4 and $67.3 \%$, respectively. Alaerts et al. (1996) demonstrated that the duckweed sewage stabilization pond system achieved 74 and $77 \%$ removal of nitrogen and phosphorus, respectively.

In this study, the removal of fecal coliform in the duckweed pond ranged between 3 and $5 \operatorname{logs}$. The recovery of nutrients from the pond may cause a deficiency in these nutrients, which might affect the fecal coliform removal. Also, the adsorption of the fecal coliform to the duckweed followed by harvesting might play a role in fecal coliform removal (El-Shafai et al. 2007). Islam et al. (1990) reported that Lemna gibba might serve as an effective environmental reservoir for pathogenic bacteria.

In this study, the harvested duckweed dry matter content ranged between 5.4 and $6.2 \%$. The dry weight ranged between 93 and $114 \mathrm{~kg} / \mathrm{ha} /$ day. The protein content of the dry matter ranged between 24.8 and $30.4 \%$. The phosphorus content ranged between 0.71 and $0.75 \%$ (Table 6). This range is similar to what has been published in the literature. The dry matter content of lemna species ranged between 5.4 and 6.2\% (Ennabili et al. 1998). Van der Steen et al. (1999) reported the dry Lemna gibba yield was about $74-164 \mathrm{~kg} / \mathrm{ha} /$ day. Ennabili et al. (1998) reported that a protein content of $17.8 \%$ in the dry matter of Lemna gibba

Table 4 ABR total solids

\begin{tabular}{lllllc}
\hline HRT & Influent TS (g/day) & Effluent TS (g/day) & TS in tank (g/day) & Unaccounted TS (g/day) & Calc. TS accum (g/day) \\
\hline 24 & $4.44 \pm 0.53$ & $1.23 \pm 0.31$ & $1.50 \pm 0.42$ & $1.70 \pm 0.48$ & $3.20 \pm 0.6$ \\
18 & $4.80 \pm 0.49$ & $1.24 \pm 0.25$ & $1.80 \pm 0.5$ & $1.76 \pm 0.53$ & $3.56 \pm 0.63$ \\
12 & $7.50 \pm 0.65$ & $2.22 \pm 0.38$ & $3.68 \pm 0.64$ & $3.04 \pm 0.58$ & $5.28 \pm 0.48$ \\
8 & $16.50 \pm 0.85$ & $3.90 \pm 0.53$ & $7.02 \pm 0.8$ & $5.60 \pm 0.41$ & $12.60 \pm 0.9$ \\
\hline
\end{tabular}


Table 5 The performance of the duckweed pond as a post-treatment for the ABR effluent

\begin{tabular}{|c|c|c|c|c|c|c|c|}
\hline \multirow[t]{2}{*}{ Parameters } & \multirow[t]{2}{*}{ Unit } & \multicolumn{3}{|c|}{$12 \mathrm{~h} \mathrm{ABR} / 10$ days DWP } & \multicolumn{3}{|c|}{$12 \mathrm{~h} \mathrm{ABR} / 15$ days DWP } \\
\hline & & $\mathrm{ABR}$ & DWP & $\% \mathrm{R}$ & $\mathrm{ABR}$ & DWP & $\% \mathrm{R}$ \\
\hline Temperature & ${ }^{\circ} \mathrm{C}$ & 23.3 & 25 & - & 23.3 & 24 & - \\
\hline $\mathrm{pH}$ & $\mathrm{Mg} / \mathrm{l}$ & 7.2 & 8.5 & - & 7.2 & 8.3 & - \\
\hline Tot. COD & $\mathrm{Mg} / \mathrm{l}$ & $154.5 \pm 45.6$ & $72.7 \pm 19.0$ & $53.6 \pm 7.5$ & $154.5 \pm 45.6$ & $49.4 \pm 16.1$ & $58.4 \pm 7.9$ \\
\hline Sol. COD & $\mathrm{Mg} / \mathrm{l}$ & $78.8 \pm 24.6$ & $43.8 \pm 11.0$ & $62.9 \pm 8$ & $78.8 \pm 24.6$ & $34.6 \pm 7.7$ & $64.2 \pm 8.4$ \\
\hline Tot. BOD & $\mathrm{Mg} / \mathrm{l}$ & $97.4 \pm 39.5$ & $39.9 \pm 8.2$ & $58.6 \pm 8.1$ & $97.4 \pm 39.5$ & $17.3 \pm 6.1$ & $66 \pm 8$ \\
\hline Sol. BOD & $\mathrm{Mg} / \mathrm{l}$ & $54.8 \pm 20.8$ & $20.9 \pm 5.5$ & $60.7 \pm 8.3$ & $54.8 \pm 20.8$ & $8.4 \pm 3.0$ & $63.1 \pm 8.5$ \\
\hline Ammonia & $\mathrm{Mg} / \mathrm{l}$ & $29.4 \pm 7.3$ & $10.3 \pm 5.6$ & $65.0 \pm 6.2$ & $29.4 \pm 7.3$ & $8.4 \pm 3.5$ & $71.2 \pm 6.5$ \\
\hline TKN & $\mathrm{Mg} / \mathrm{l}$ & $38.0 \pm 9.2$ & $12.5 \pm 2.6$ & $66.7 \pm 8.5$ & $38.0 \pm 9.2$ & $10.0 \pm 1.5$ & $73.4 \pm 8.8$ \\
\hline $\begin{array}{l}\text { Tot. } \\
\text { phosphorus }\end{array}$ & $\mathrm{Mg} / \mathrm{l}$ & $6.8 \pm 1.4$ & $3.5 \pm 1.0$ & $53.4 \pm 3.2$ & $6.8 \pm 1.4$ & $2.7 \pm 0.9$ & $67.3 \pm 3.7$ \\
\hline TSS & $\mathrm{Mg} / \mathrm{l}$ & $73.7 \pm 24.0$ & $41.8 \pm 12.0$ & $39.8 \pm 6$ & $73.7 \pm 24.0$ & $32.9 \pm 7.0$ & $52.4 \pm 7.2$ \\
\hline $\begin{array}{l}\text { Oil and } \\
\text { grease }\end{array}$ & $\mathrm{Mg} / \mathrm{l}$ & $17.8 \pm 6.5$ & $10.5 \pm 2.8$ & $41.4 \pm 6.8$ & $17.8 \pm 6.5$ & $9.5 \pm 0.5$ & $47.5 \pm 7$ \\
\hline VFA & $\mathrm{Mg} / \mathrm{l}$ & $19.1 \pm 4.0$ & $9.2 \pm 2.3$ & $42.0 \pm 5.2$ & $19.1 \pm 4.0$ & $8.5 \pm 2.0$ & 46.36 .4 \\
\hline $\mathrm{FC}$ & $\begin{array}{l}\mathrm{Cfu} / \\
\quad 100 \mathrm{ml}\end{array}$ & $4.5 \mathrm{E}+08 \pm 1.7 \mathrm{E}+08$ & $3.6 \mathrm{E}+04 \pm 2.7 \mathrm{E}+04$ & 99.754 & $4.5 \mathrm{E}+08 \pm 1.7 \mathrm{E}+08$ & $0.8 \mathrm{E}+03 \pm 0.2 \mathrm{E}+03$ & 99.892 \\
\hline
\end{tabular}

Average of 22 samples

Table 6 Duckweed production and nutrient content

\begin{tabular}{llccc}
\hline Parameters & Unit & Min & Max & Average \\
\hline Fresh yield & Kg/ha/day & 1,330 & 2,190 & $1,813 \pm 431.1$ \\
Dry yield & Kg/ha/day & 93 & 114 & $105.5 \pm 10.6$ \\
Dry matter & \%Dry matter & 5.4 & 6.2 & $5.8 \pm 0.3$ \\
Protein content & \%Protein content & 24.8 & 30.4 & $27.1 \pm 2.8$ \\
Phosphorus content & \%Phosphorus content & 0.71 & 0.75 \\
\hline
\end{tabular}

grew on sewage. Alaerts et al. (1996) reported that the protein content of dry duckweed ranged between 15.8 and $28 \%$. Hammouda et al. (1995) reported a higher protein content for Lemna gibba (31.8-47.1\%) grown on a mixture of Nile water and human sewage.

Alaerts et al. (1996) reported that duckweed harvested from a sewage treatment lagoon contained total phosphorus in the range of 48 and $86 \%$ of dry matter biomass. Ennabili et al. (1998) reported an average value of $74 \%$ total phosphorus in the dry matter of Lemna gibba.

\subsection{Performance of the entire treatment system}

The overall efficiency of the whole treatment system of this study for carbonaceous matter removal is considered good. Removal values of COD ranged between 84.9 and $93.3 \%$; corresponding residual values were 44.1 and $104.7 \mathrm{mg} \mathrm{O}_{2} / 1$ (Figs. 5 and 6).

Total suspended solids removal ranged between 77 and $89.7 \%$, with residual values of 29.9 and $43.5 \mathrm{mg} / \mathrm{l}$.
Residual total phosphorus in the final effluent ranged between 2.7 and $4.2 \mathrm{mg} / \mathrm{l}$; this corresponds to an overall removal of 64 and $71.4 \%$. Total Kjeldahl nitrogen removal values ranged from 72.8 to $85.2 \%$; corresponding residual values were 10 and $17.6 \mathrm{mg} / \mathrm{l}$. Results of bacteriological examination revealed that the density of fecal coliform ranged between $0.8 \times 10^{3}$ and $3.6 \times 10^{4} \mathrm{cfu}$.

During the experimental run, 12-h HRT ABR followed by 15-day HRT DWP, an improvement in the treatment efficiency was achieved.

Increasing the hydraulic retention time from 10 days to 15 days in the DWP led to an increase in the average percentage removal value of total COD from 88.6 to $92.2 \%$ and of soluble COD from 84.4 to $88.9 \%$. Corresponding values of both total and soluble BOD increased from 86.3 to $94.1 \%$ and from 82.4 to $88.5 \%$. The average percentage removal value of total suspended solids increased from 82.5 to $86.2 \%$. Results of bacteriological examination revealed that the average density of fecal coliform decreased from $3.6 \mathrm{E}+04$ to $0.8 \mathrm{E}+03 \mathrm{cfu} / 100 \mathrm{ml}$. 
Fig. 5 Efficiency of the entire treatment system using 12-h ABR and 10-day DWP
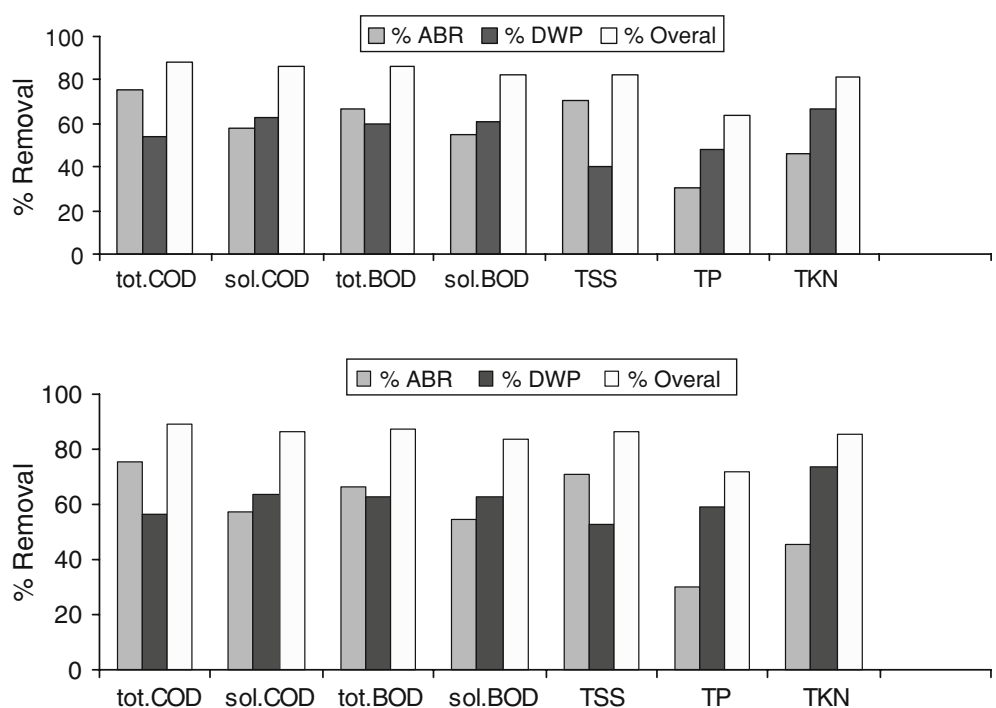

Fig. 6 Efficiency of the entire treatment system using 12-h $\mathrm{ABR}$ and 15-day DWP

Table 7 Performance of the entire treatment system using 12-h ABR and 15-day DWP

\begin{tabular}{|c|c|c|c|c|c|c|}
\hline \multirow[t]{2}{*}{ Parameters } & \multirow[t]{2}{*}{ Unit } & \multicolumn{4}{|l|}{ 12-h ABR/15-day DWP } & \multirow{2}{*}{$\begin{array}{l}\text { Egyptian } \\
\text { law }\end{array}$} \\
\hline & & Raw & ABR & DWP & $\% \mathrm{R}$ & \\
\hline Temperature & ${ }^{\circ} \mathrm{C}$ & 24.3 & 23.3 & 24 & - & \\
\hline $\mathrm{pH}$ & & 6.9 & 7.2 & 8.3 & - & \\
\hline Tot. COD & $\mathrm{Mg} / \mathrm{l}$ & $632.8 \pm 88.6$ & $154.5 \pm 45.6$ & $49.4 \pm 16.1$ & $92.2 \pm 1.5$ & 80 \\
\hline Sol. COD & $\mathrm{Mg} / \mathrm{l}$ & $312.1 \pm 68.9$ & $78.8 \pm 24.6$ & $34.6 \pm 7.7$ & $88.9 \pm 2$ & \\
\hline Tot. BOD & $\mathrm{Mg} / \mathrm{l}$ & $292.4 \pm 76.8$ & $97.4 \pm 39.5$ & $17.3 \pm 6.1$ & $94.1 \pm 1.8$ & 40 \\
\hline Sol. BOD & $\mathrm{Mg} / \mathrm{l}$ & $119.4 \pm 57.6$ & $54.8 \pm 20.8$ & $8.4 \pm 3.0$ & $88.5 \pm 2.6$ & \\
\hline Ammonia & $\mathrm{Mg} / \mathrm{l}$ & $24.6 \pm 12.3$ & $29.4 \pm 7.3$ & $8.4 \pm 3.5$ & $65.2 \pm 8.7$ & \\
\hline TKN & $\mathrm{Mg} / \mathrm{l}$ & $66.6 \pm 13.2$ & $38.0 \pm 9.2$ & $10.0 \pm 1.5$ & $85.2 \pm 6.4$ & \\
\hline Tot. phosphorus & $\mathrm{Mg} / \mathrm{l}$ & $9.8 \pm 2.1$ & $6.8 \pm 1.4$ & $2.7 \pm 0.9$ & $71.4 \pm 5.8$ & \\
\hline TSS & $\mathrm{Mg} / \mathrm{l}$ & $249.9 \pm 67.5$ & $73.7 \pm 24.0$ & $32.9 \pm 7.0$ & $86.2 \pm 1.9$ & 40 \\
\hline Oil and grease & $\mathrm{Mg} / \mathrm{l}$ & $53.8 \pm 12.0$ & $17.8 \pm 6.5$ & $9.5 \pm 0.5$ & $81.8 \pm 1.2$ & 10 \\
\hline VFA & $\mathrm{Mg} / \mathrm{l}$ & $39.9 \pm 5.0$ & $19.1 \pm 4.0$ & $8.5 \pm 2.0$ & $78.5 \pm 1.8$ & \\
\hline $\mathrm{FC}$ & $\mathrm{Cfu} / 100 \mathrm{ml}$ & $1.6 \mathrm{E}+09 \pm 8.6 \mathrm{E}+08$ & $4.5 \mathrm{E}+08 \pm 1.7 \mathrm{E}+08$ & $0.8 \mathrm{E}+03 \pm 0.2 \mathrm{E}+03$ & 99.9925 & 1000 \\
\hline
\end{tabular}

Average of 22 samples

From the results presented in Table 7, it can be seen that the treatment system looks practically feasible for domestic wastewater treatment. Comparing the physico-chemical and biological quality of the treated wastewater with the Egyptian standards that set out conditions and criteria for the disposal of wastewater by irrigation of agricultural land, the treated wastewater could be used for restricted irrigation.

\section{Conclusion}

- The characteristics of raw domestic sewage invested in this study can be categorized as medium-strength wastewaters as per world-recognized classification. The
COD:BOD ratio of 2.3:1 agrees with the ratio obtained worldwide by many research projects.

- Operating the ABR at hydraulic retention times ranging from 8 to $24 \mathrm{~h}$ gave satisfactory results. COD removal was between 68 and $82 \%$. The 12- and 18-h HRT gave close results, as an indication for the possible selection of the 12-h HRT as the optimum operation for the ABR based on economic advantage.

- The ABR compartmentalized structure gave results higher than those produced by a one-stage digester and similar to those produced by a two-phase anaerobic digestion process.

- Duckweed ponds as post-treatment operated at 10 days and 15 days gave the best results at 15-day HRT, where it was possible to remove $71 \%$ nitrogen and $67 \%$ 
phosphorus in the form of protein-rich dry duckweed of $105 \mathrm{~kg} / \mathrm{ha} /$ day on average. Also fecal coliform removal between 3 to $5 \operatorname{logs}$ could be achieved.

- The final treated domestic sewage characteristics proved its compliance with the Egyptian standards for use in restricted irrigation.

Open Access This article is distributed under the terms of the Creative Commons Attribution Noncommercial License which permits any noncommercial use, distribution, and reproduction in any medium, provided the original author(s) and source are credited.

\section{References}

Alaerts GJ, Mahbubar MDR, Kelderman P (1996) Performance analysis of a full-scale duckweed covered sewage lagoon. Water Res 30(4):843-852. doi:10.1016/0043-1354(95)00234-0

APHA (2002) Standard methods for water and wastewater examinations, 20th edn. American Public Health Association, Washington

Batchmann A, Beard VL, McCarty PL (1983) In: Wu YC, Smith ED (ed) Comparison of fixed film reactors with a modified sludge blanket reactor, fixed film biological processes for wastewater treatment. Noyes Data, NJ

Boopathy R (1998) Biological treatment of swine waste using anaerobic baffled reactor (ABR). Bioresour Technol 64:1-6. doi: 10.1016/S0960-8524(97)00178-8

Collivignarelli G, Farneti A, Bassetti A, Barbaresi U (1990) Anaerobic-aerobic treatment of municipal wastewaters with full-scale UASB and attaches biofilm reactors. Water Sci Technol 22(1/2):475-482

Conley LM, Dick RI, Lion LW (1991) An assessment of the root zone method of wastewater treatment. J Water Pollt Con Fed 63:239-247

Dama P, Bell J, Foxon KM, Brouaert CJ Huang t, Buckley CA, Naidoo V, Stukey D (2005) Pilot-scale study of an anaerobic baffled reactor for the treatment of domestic wastewater. In: 3rd International Conference on Ecological Sanitation, Durban, South Africa

El-Gohary FA, Nasr FA, Wahaab RA (2000) Integrated low-cost wastewater treatment for reuse in irrigation. Int $\mathrm{J}$ Biomed Environ Sci 13:37-43

El-Hamouri B, Jellal J, Outabiht H, Nebri B, Khallayoune K, Benkerroum A et al (1995) The performance of a high-rate algal pond in the Moroccan climate. Water Sci Technol 31(12):67-74. doi:10.1016/0273-1223(95)00493-7

El-Shafai SA (2004) Nutrient valorization via duckweed based wastewater and aquaculture. Ph.D. Thesis, Wageningan University and UNESCO-IHE-Institute for Water Education, The Netherlands

El-Shafai SA, El-Gohary FA, Nasr FA, Van der steem P, Gijzen H (2007) Nutrient recovery from domestic wastewater using a UASB-duckweed ponds system. Bioresour Technol 98:798-807. doi:10.1016/j.biortech.2006.03.011

Ennabili A, Ater M, Radoux M (1998) Biomass production and NPK retention in macrophytes from wetlands of the Tingitan peninsula. Aquat Bot 62:45-56. doi:10.1016/S0304-3770(98)00075-8

Field JA, Leyendeckers MJH, Sierra-Alvarez R, Lettinga G, Habets LHA (1988) The methanogenic toxicity of bark tannins and the anaerobic biodegradability of water soluble bark matter. Water Sci Technol 20:219-240

Hammouda O, Gaber A, Abdel-Hameed MS (1995) Assessment of the effectiveness of treatment of wastewater-contaminated aquatic systems with Lemna gibba. Enzyme Microb Technol 17:317-323. doi:10.1016/0141-0229(94)00013-1
Islam SI, Drasar BS, Bradley NJ (1990) Survival of toxigenic vibrio cholerae 01 with common duckweed, Lemna minor in artificial aquatic ecosystems. Trans R Soc Trop Med Hyg 84:422-424. doi:10.1016/0035-9203(90)90345-F

Kennedy K, Barriault M (2005) Effect of recycle on treatment of aircraft de-icing fluid in an anaerobic baffled reactor. Water SA 31(3)

Korner S, Das KS, Veenstra S, Vermaat EJ (2000) The effect of pH variation at the ammonium/ammonia equilibrium in wastewater and its toxicity to Lemna gibba. Aquat Bot 71:71-78. doi: 10.1016/S0304-3770(01)00158-9

Langenhoff AAM, Intrachandra N, Stuckey DC (2000) The anaerobic treatment of dilute soluble and colloidal wastewater using an anaerobic baffled reactor; influence of hydraulic retention time. Water Res 34:1307-1317. doi:10.1016/S0043-1354(99)00236-5

Manariotis ID, Grigoropoulos SG (2002) Low-strength wastewater treatment using an anaerobic baffled reactor. Water Environ Res 74(2):170-176. doi:10.2175/106143002X139884

Metcalf and Eddy (2005) Wastewater engineering-treatment, disposal and reuse, 4th edn. McGraw-Hill, New York

Nachiayasit S, Stuckey DC (1997) The effect of schock loads on the performance on an anaerobic baffled reactor (ABR). 2. Step and transient hydraulic schoks at constant feed strength. Water Resour 31(11):2747-2754

Nasr FA, El-Shafai SA, Abo-Hegab S (1998) Suitability of treated domestic wastewater for raising Oreochromis niloticus. Egypt J Zool 31:81-94

Oron G, Willers H (1989) Effect of wastes quality on treatment efficient with duckweed. Water Sci Technol 21:639-645

Porath D, Pollock J (1982) Ammonia stripping by duckweed and its feasibility in circulating aquaculture. Aquat Bot 13:125-131. doi:10.1016/0304-3770(82)90046-8

Rusoff LL, Blakeney EW Jr, Culley DD Jr (1980) Duckweed (Lemnaceae family): a potential source of protein and amino acids. J Agric Food Chem 28:848-850. doi:10.1021/jf60230a040

Sasse (1998) Decentralized wastewater treatment in developing countries (DEWATS). BORDA publication

She Z, Zheng X, Yang B, Jin C, Gao M (2006) Granule development and performance in sucrose fed anaerobic baffled reactors. $\mathrm{J}$ Biotechnol 122:198-208. doi:10.1016/j.jbiotec.2005.09.004

Shereif MM, Easa ME, El-Samra MI, Mancy KH (1995) A demonstration of wastewater treatment for reuse applications in fish production and irrigation in Suez, Egypt. Water Sci Technol 32(11):137-144. doi:10.1016/0273-1223(96)00127-8

Skillcorn P, Spita W, Journey W (1993) Duckweed aquaculture a new aquatic farming system for developing countries. The International Bank, Washington, DC

Smith MD, Moclyowati I (2001) Duckweed based wastewater treatment (DWWT): design guidelines for hot climate. Water Sci Technol 43(11):291-299

Uyanik S (2003) A novel anaerobic reactor: split fed anaerobic baffled reactor (SFABR). Turk J Eng Environ Sci 27:339-345

van der Last ARM, Lettinga G (1992) Anaerobic treatment of domestic sewage under moderate climate (Dutch) conditions using upflow reactors at increased superficial velocities. Water Sci Technol 25:167-178

van der Steen P, Bremer A, Van Buuren J, Oron G (1999) Posttreatment of UASB reactor effluent integrated duckweed and stabilization pond system. Water Res 3(3):615-620. doi: 10.1016/S0043-1354(98)00270-X

Wanasen S (2003) Upgrading conventional septic tanks by integrating in-tank baffles, Thesis. EV-03-20, Asian Institute of Technology (AIT), Bangkok

Yu H, Anderson GK (1996) Performance of a combined anaerobic reactor for municipal wastewater treatment at ambient temperature. Resour Conserv Recycling 17:259-271. doi:10.1016/ 0921-3449(96)01101-9 